\title{
DIAGNOSTIC VALUE OF CSF PROTEINS ASSAY IN DIFFERENTIAL DIAGNOSIS OF CNS DISEASE
}

\author{
Dragana Vukosavljević ${ }^{1}$, Ljiljana Bumbaširević2, Aleksandra Stefanović3, Marina Stojanov ${ }^{3}$ \\ ${ }^{1}$ Institute of Medical Biochemistry, \\ Clinical Centre of Serbia, Belgrade, Serbia and Montenegro \\ 2Institute of Neurology, Clinical Centre of Serbia, Belgrade, Serbia and Montenegro \\ 3institute of Medical Biochemistry, Faculty of Pharmacy, University of Belgrade, \\ Belgrade, Serbia and Montenegro
}

\begin{abstract}
Summary: The differential diagnosis between inflammatory and noninflammatory diseases of CNS includes CSF quantitative measurements of immunoglobulin and albumin concentrations and their comparison to the serum. For that purpose we estimated the concentrations of albumin and immunoglobulin G both in CSF and serum of patients with inflammatory and noninflammatory diseases of CNS. Parallely, these parameters were determined in the control group composed of patients having the values of investigated parameters within reference ranges. The obtained data were statistically evaluated by nonparametric Mann-Whitney test. The values of calculated CSF/albumin ratio have shown significant differences between the both patient groups and the control one $(\mathrm{p}<0.001)$. It proves that in each examined group the blood brain barrier is damaged. For the assessment of intrathecal IgG synthesis we have calculated both IgG/albumin index and Schuller index. The comparison of the values obtained for patients with noninflammatory diseases to the control one, revealed no statistically significant differences $(p>0.05$ ). On the contrary, significant difference have been observed between the group with inflammatory diseases and the control $(p<0.05)$, proving the existence of IgG intrathecal synthesis. Values of both indexes were much higher in patients with inflammatory than noninflamatory diseases, meaning that they can be used in differential diagnosis.
\end{abstract}

Key words: cerebrospinal fluid, albumin, immunoglobulin G, CSF/albumin ratio, IgG/albumin index

\section{Introduction}

Many disorders of the central nervous system (CNS) are accompanied by increased protein concentration in the cerebrospinal fluid (CSF), which can be attributable to an altered permeability of the bloodbrain barrier, to intrathecal synthesis of immunoglobulins, or to the combination of both (1). Examination of CSF total protein and specific proteins is used chiefly to detect increased permeability of the bloodbrain barrier to plasma proteins or to detect increased intrathecal production of immunoglobulins. The degree of permeability of the blood-brain barrier can

\footnotetext{
Address for correspondence:

Prof. Dr. Marina Stojanov

Institute of Medical Biochemistry

Faculty of Pharmacy

Vojvode Stepe 450

11221 Belgrade, P. Box 146

Serbia and Montenegro
}

be evaluated by immunochemical measurements of albumin in CSF and in serum specimens obtained at the same time. Albumin is a particulary suitable protein because it is neither synthesized nor metabolized intrathecally. Demonstration of increased intrathecal immunoglobulin synthesis resulting from infiltration of IgG-producing lymphocytes inside brain and spinal cord is a specific indication for the presence of inflammation in the CNS. Albumin can cross the bloodbrain barrier, but in contrast to IgG, cannot be produced in the CNS itself (2).

Several disorders of the CNS such as bacterial meningitis, multiple sclerosis and other CNS inflammatory diseases, are associated with an increase in protein concentration in $\operatorname{CSF}(3,4)$. In this context, the examination of the CSF includes quantitative measurements of immunoglobulin and albumin concentrations in comparison with the serum. The purpose of this work was to establish the degree of blood brain barrier damage in inflammatory and noninflam- 
matory diseases, intrathecal synthesis of $\operatorname{IgG}$ and to use the data in differential diagnosis between the two types of CNS diseases.

\section{Materials and Methods}

The investigations were performed on patients with inflammatory and noninflammatory disease of CNS. Patients with inflammatory disease $(n=20)$ had clinically confirmed diagnosis of tuberculosis meningitis. In the group with noninflamatory disease $(n=20)$ were patients with diagnosis of poliradiculoneuritis, vascular disorders and brain carcinoma, while tuberculoses meningitis was excluded. Patients who had normal concentrations of total proteins, albumin and globulins in both serum and CSF were used as the control.

CSF and blood were obtained by lumbar puncture (L5-L6) and venipuncture, respectively. Blood samples were drawn without anticoagulant and centrifuged (3000 g for $10 \mathrm{~min}$ at $4{ }^{\circ} \mathrm{C}$ ), and serum was harvested. All samples were stored at $-20{ }^{\circ} \mathrm{C}$ before being processed. Albumin and IgG were measured in serum and unconcentrated CSF by immunoturbidimetry using Turbitimer (Dade-Behring) with calibrators and internal controls provided by Dade-Behring and according to manufacturer's recommendations.

As a mirror of blood-CSF barrier status, the $\mathrm{CSF} /$ serum albumin ratio was calculated; its threshold of positivity varied between $6 \times 10^{-3}$ and $8 \times$ $10^{-3}$ with the age of patients. To detect intrathecal synthesis of IgG (ISI), we calculated the IgG/albumin index (5) and the Schuller index (6). The IgG/albumin index was calculated by the following formula:

IgG/Albumin index $=\left(\operatorname{lgG}_{\mathrm{CSF}} / \operatorname{lgG}_{\text {serum }}\right) /\left(\right.$ albumin $_{\mathrm{CSF}} / \mathrm{albu}-$ $\min _{\text {serum }}$ )

and was positive above 0.65. The Schuller index was defined by the following formula:

ISI $(\mathrm{mg} / \mathrm{L})=\operatorname{IgG}_{\mathrm{CSF}}-\left\{30+\left[\left(\right.\right.\right.$ albumin $\left.\left._{\mathrm{CSF}}-240\right) / 60\right] \times$ $\left.\operatorname{IgG}_{\text {serum }}\right\}$

Intrathecal synthesis of IgG is suspected when the result is $>0 \mathrm{mg} / \mathrm{L}$.

\section{Results and Discussion}

The data we have obtained for CSF albumin and immunoglobulin G are presented in Table I.

The CSF albumin concentration was significantly increased both in patients with inflammatory and noninflamatory disease, which was already confirmed in the literature (7). Significant difference was found between each patient group and the control one $(\mathrm{p}<$ $0.001)$, but not between the patient groups themself (p > 0.05).

The concentrations of IgG in CSF were increased in both groups of patients, and significant differences was found in comparison to the control ( $p<$ 0.001 ), which is in agreement with literature data (8). The differences in IgG concentration were also found between patients with inflamatory and noninflamatory CNS disease ( $p<0.05)$.

For the evaluation of the blood-brain barrier damage, we have calculated the albumin index. The results are presented in Table II.

Compared to the control group there was a significant increament in patients both with noninflamatory ( $p<0.001)$ and inflamatory disease $(p<0.001)$. No significant differences were found for albumin index between the two patient groups ( $p>0.05$ ).

The preferred method for the measurement of blood-CSF barrier dysfunction is the analysis of albumin quotient and its evaluation with regard to the agerelated reference range (9). The analysis of total protein is still frequently used for evaluation of barrier dysfunction because it does offer some clinical value in spite of its broad reference range, i.e., lower sensitivity, and specificity than albumin quotient. Due to systematic inflammatory diseases with high total protein concentrations in blood, high total concentrations in CSF are subsrequently observed. This could lead to falce positive interpretation but could be avoided by using the albumin quotient (10).

The immunoglobulin index was calculated in order to prove possible intrathecal synthesis of IgG. In patients with inlamatory CNS disease, the index was increased, which was not the case with noninflamatory diseases (Table III).

Table I Concentrations of CSF albumin and immunoglobulin G in the control group (I) and patients with inflammatory (II) and noninflammatory CSN disease

\begin{tabular}{|c|c|c|c|c|c|c|}
\hline $\mathrm{N}$ & $\begin{array}{c}\mathrm{I} \\
(\overline{\mathrm{x}} \pm \mathrm{SD})\end{array}$ & $(\overline{\mathrm{x}} \pm \mathrm{SD})$ & $\begin{array}{c}\text { III } \\
(\overline{\mathrm{x}} \pm \mathrm{SD})\end{array}$ & $\begin{array}{c}\mathrm{P} \\
(\mathrm{I}-\mathrm{II})\end{array}$ & $\begin{array}{c}\mathrm{P} \\
(\mathrm{I}-\mathrm{III})\end{array}$ \\
\hline \multicolumn{7}{|c|}{ Albumin $(\mathrm{mg} / \mathrm{L})$} \\
\hline 20 & $206.6 \pm 45.2$ & $1314 \pm 114.7$ & $1478 \pm 142.4$ & $<0.001$ & $<0.001$ & $>0.05$ \\
\hline \multicolumn{7}{|c|}{ IgG $(\mathrm{mg} / \mathrm{L})$} \\
\hline 20 & $26.09 \pm 3.12$ & $334 \pm 30.3$ & $152 \pm 12.5$ & $<0.001$ & $<0.001$ & $<0.05$ \\
\hline
\end{tabular}


Table II Blood-CSF barrier permeability abnormalities assessed by the albumin ratio

\begin{tabular}{|l|c|c|}
\hline \multicolumn{1}{|c|}{ Groups } & CSF/albumin ratio & P \\
\hline Control (I) & 4.75 & (II vs I) \\
\hline Inflammatory diseases (II) & 36.40 & 0.001 \\
\hline Noninflammatory diseases (III) & 35.10 & (III vs I) \\
& & $<.001$ \\
\hline $\begin{array}{l}\text { Inflammatory/ } \\
\text { noninflammatory diseases }\end{array}$ & 0.48 & $>0.05$ \\
\hline
\end{tabular}

Table III Intrathecal IgG synthesis assessed by the IgG/albumin index and the Schuller index

\begin{tabular}{|l|c|c|c|c|}
\hline \multicolumn{1}{|c|}{$\begin{array}{c}\text { Groups } \\
(\mathrm{n}=20)\end{array}$} & $\begin{array}{c}\text { IgG/albumin } \\
\text { index } \\
>0.65, \mathrm{n}(\%)\end{array}$ & $\mathrm{p}$ & $\begin{array}{c}\text { Schuller index } \\
>0 \mathrm{mg} / \mathrm{L}, \mathrm{n}(\%)\end{array}$ & $\mathrm{p}$ \\
\hline Control (I) & 0.48 & - & 0.539 & - \\
\hline $\begin{array}{l}\text { Inflammatory } \\
\text { diseases (II) }\end{array}$ & 0.77 & 0.001 & 1.078 & $11(55)$ \\
\hline $\begin{array}{l}\text { Noninflammatory } \\
\text { diseases (III) }\end{array}$ & $0.39(60)$ & $>0.05$ & 0.420 & (II vs. I) \\
\hline $\begin{array}{l}\text { Inflammatory/ } \\
\text { noninflammatory }\end{array}$ & 1.974 & $<0.05$ & 2.031 & (III vs.I) \\
\hline
\end{tabular}

This finding confirm the existance of IgG synthesis as a response to the infectious agens (11). By comparisson of IgG index between the investigated groups, statistically significant differences was found ( $\mathrm{p}<0.001)$.

The determination of CSF/serum quotients is regarded as a suitable evaluation and interpretation method for the detection of intrathecal IgG, IgA or IgM synthesis. As reviewed recently, the frequently used IgG Index or IgG Synthesis rate give up to $90 \%$ falce-positive values for high albumin quotients (blood-
CSF barrier dysfunction) compared to the gold standard, which is the detection of oligoclonal bands on isoelectric focusing (IEF). Regarding quantitative analyses of intrathecal immunoglobulin synthesis, there is an agreement to refer to hyperbolic discrimination line, expressed in either a numerical or graphical format $(12,13)$. This is often facilitated by use of PC-based software for evaluation of CSF data profiles, and thus knowledge-based interpretation programs support routine CSF analysis $(12,14)$. 


\title{
DIJAGNOSTIČKI ZNAČAJ ODREĐIVANJA PROTEINA U CEREBROSPINALNOJ TEČNOSTI KOD DIFERENCIJALNE DIJAGNOSTIKE OBOLJENJA CNS-a
}

\author{
Dragana Vukosavljević1, Ljiljana Bumbaširević2, Aleksandra Stefanović3, Marina Stojanov ${ }^{3}$ \\ ${ }^{1}$ Institut za medicinsku biohemiju, Klinički centar Srbije, Beograd, Srbija i Crna Gora \\ 2Institut za neurologiju, Klinički centar Srbije, Beograd, Srbija i Crna Gora \\ 3 Institut za medicinsku biohemiju, Farmaceutski fakultet Univerziteta u Beogradu, \\ Beograd, Srbija i Crna Gora
}

\begin{abstract}
Kratak sadržaj: Diferencijalna dijagnoza inflamatornih i neinflamatornih oboljenja CNS-a, obuhvata kvantitativno određivanje koncentracija imunoglobulina i albumina, kao i njihovo poređenje sa serumom. Koncentracije albumina i imunoglobulina G određene su u cerebrospinalnoj tečnosti (CST) u serumu pacijenata sa inflamatornim i neinflamatornim oboljenjima CNS-a. Ovi parametri određeni su i u kontrolnoj grupi, sačinjenoj od pacijenata kod kojih su ispitivani parametri bili u granicama referentnih vrednosti. Dobijeni rezultati statistiški su obrađeni neparametarskim Mann-Whitney testom. Izračunate vrednosti CSF/albumin pokazale su statistički značajne razlike između obe grupe pacijenata i kontrolne grupe $(p<0,001)$. Ovo dokazuje da je kod obe grupe pacijenata krvno moždana barijera oštećena. Za procenu intratekalne sinteze IgG izračunati su Ig/albumin indeks i Schuller-ov index. Poređenjem vrednosti za pacijente sa nezapaljenskim oboljenjima i kontrolne grupe nisu nađene značajne razlike $(p>0,05)$. Suprotno, statistički značajne razlike uočene su između grupe sa inflamatornim oboljenjima i kontrolne grupe $(p<0,05)$, što ukazuje na postojanje intratekalne sinteze IgG-a. Vrednosti izračunatih indeksa za zapaljenske procese bile su značajno više u odnosu na nezapaljenska oboljenja ( $p$ $<0,05)$, što se može iskoristiti za diferencijalnu dijagnozu ovih oboljenja.
\end{abstract} indeks

Ključne reči: cerebrospinalna tečnost, albumin, imunoglobulin G, odnos CSF/albumin, IgG/albumin

\section{References}

1. Fishman RA. Cerebrospinal Fluid in Disease of the Nervous System. Philadelphia: WB Saunders Co, 1992; 142.

2. Reiber H. External quality assessment in clinical neurochemistry: survey of analysis for cerebrospinal fluid (CSF) proteins based on CSF/serum quotients. Clin Chem 1995; 41: 256-63.

3. Lolli F, Halawa I, Link H. Intrathecal synthesis of IgG, $\operatorname{IgA}, \operatorname{Ig} M$ and $\operatorname{IgD}$ in untreated multiple sclerosis and controls. Acta Neurol Scand 1989; 80: 238-47.

4. Reiber H, Felgenhauer K. Protein transfer at the blood cerebrospinal fluid barrier and the quantitation of the humoral immune response within the central nervous system. Clin Chim Acta 1987; 163: 319-28.

5. Link H, Tibbing G. Principles of albumin and IgG analyses in neurological disorders. III. Evaluation of IgG synthesis within the central nervous system in multiple sclerosis. Scand J Clin Lab Invest 1977; 37: 397-401.

6. Schuller E, Sagar HJ. Central nervous system IgG synthesis in multiple sclerosis. Application of a new formula. Acta Neurol Scand 1983; 67: 365-71.

7. Delpech B, Lichtblan E. Etude quantitative des immunoglobulines $G$ et de l'albumine du liquide chephalorachiden. Clin Chem Acta 1972; 37: 15-23.

8. Tibbling G, Link H, Oehmann S. Principles of albumin and IgG analysis in neurological disorders. I. Establish- ment of reference values. Scand J Clin Lab Invest 1977; 37: 385-90.

9. Sindic CJM, Van Antwerpen M-P, Goffette S. The intrathecal humoral immune response: Laboratory analysis and clinical relevance. Clin Chem Lab Med 2001; 39: 333-40.

10. Blennow K, Fredman P, Wallin A, et.al. Protein analysis in cerebrospinal fluid. II Reference values derived from healthy individuals 18-88 years of age. Eur Neurol 1993; 33: 129-33.

11. Cho TY, Park SC, Cho SN, et.al. Intrathecal synthesis of immunoglobulin $\mathrm{G}$ and mycobacterium tuberculosisspecific humoral immune response in tuberculous meningitis. Clin Diagn Lab Immunol 1995; 2: 361- 4.

12. Reiber H, Peter JB. Cerebrospinal fluid analysis - disease-related data patterns and evaluation programs. J Neirol Sci 2001; 184: 101-22.

13. Verbeek MM, de Rens HRM, Weykamp CW. A comparison of techniques for the detection of oligoclonal $\mathrm{IgG}$ bands in cerebrospinal fluid and serum results of the Dutch Control Survey. Clin Chem 2002; 48: 1578-80.

14. Reiber H, Thompson JE, Grimsley G, et.al. Quality Assurance for Cerebrospinal Fluid Protein Analysis: International Consensus by Internet-Based Group Discussion. Clin Chem Lab Med 2003; 41 (3): 331-37.

Received: December 9, 2004

Accepted: December 16, 2004 